\title{
Pengaruh Penerapan Model Pembelajaran Berbasis Masalah DiSERTAI TEKNIK BERIKAN UANGNYA TERHADAP HASIL BELAJAR MATEMATIKA SISWA KELAS VIII SMPN 16 PADANG
}

\author{
The EFfect of Problem Based Learning ApPlication Model BaSed on Give \\ MONEY TECHNIQUE TOWARD STUDENTS' MATHEMATICAL LEARNING RESULTS VIII \\ SMPN 16 PADANG
}

\author{
Mutiara Nofa Nst ${ }^{1}$ dan $_{\text {Rahmi }}{ }^{2}$ \\ 1,2 Program Studi Pendidikan Matematika, STKIP PGRI SUMBAR \\ Padang, Sumatera Barat, Indonesia \\ mutiaranofanst@gmail.com
}

\begin{abstract}
Abstrak
Penelitian ini dilatarbelakangi oleh hasil belajar siswa masih rendah dan masih banyak yang belum mencapai Kriteria Ketuntasan Minimal (KKM). Penelitian bertujuan untuk mengetahui apakah hasil belajar matematika siswa dengan menerapkan model pembelajaran berbasis masalah disertai teknik berikan uangnya lebih baik daripada hasil belajar matematika siswa dengan pembelajaran konvensional pada siswa kelas VIII SMP Negeri 16 Padang. Jenis penelitan adalah penelitian eksperimen dengan rancangan random terhadap subjek. Terpilih kelas VIII 6 sebagai kelas eksperimen dan kelas VIII 5 sebagai kelas kontrol. Instrumen penelitian yang digunakan adalah tes akhir berbentuk esai dengan reliabilitas tes adalah $r_{11}=0,7062$. Statistik uji yang digunakan untuk pengujian hipotesis adalah uji $\mathrm{t}$ satu pihak. Hasil uji hipotesis diperoleh $t_{\text {hitung }}=1,78$ dan $t_{\text {tabel }}=1,67$ dengan $\alpha=0,05$, maka $t_{\text {hitung }}>t_{\text {tabel }}$ dengan demikian hipotesis penelitian diterima. Jadi dapat disimpulkan bahwa hasil belajar matematika siswa dengan menerapkan model pembelajaran berbasis masalah disertai teknik berikan uangnya lebih baik daripada hasil belajar matematika siswa dengan menerapkan pembelajaran konvensional pada kelas VIII SMP Negeri 16 Padang.

Kata Kunci: Hasil Belajar Matematika, Model Pembelajaran Berbais Masalah, Teknik Berikan Uangnya.
\end{abstract}

\begin{abstract}
The background of this research by outcomes of student study still low and still many students of yet reached the minimum completeness criteria (KKM). The purpose of this research to know what the outcomes of study mathematics students with apply the problem based learning model with techniques give the money better than aplly the conventional learning of study at eighth grade in SMPN 16 Padang. The kind of this research is experimental research with design is random by the subject. Selected class VIII 6 as experimental class and VIII 5 as control class. The instruments of this research is test like essay with use reliability $r_{11}=0,7062$. Statistic test used for hypothesis testing is $t$-test of the parties. Hypothesis test result obtain $t_{\text {count }}=1,78$ and $t_{\text {table }}=$ 1,67 with $\alpha=0,05$, then $t_{\text {count }}>t_{\text {table }}$ so the hypothesis of this research is accepted. So, it can conclude that result of study in mathematics with apply the problem based learning model with techniques give the money better than aplly the conventional learning of study at eighth grade in SMPN 16 Padang.
\end{abstract}

Keyword: Mathematics Learning Outcomes, Problem Based Learning Model, Techniques Give The Money. 


\section{Pendahuluan}

Matematika adalah salah satu ilmu dasar yang mempunyai peranan penting dalam upaya penguasaan ilmu pengetahuan dan teknologi. Untuk menguasai dan menciptakan teknologi di masa depan diperlukan penguasaan matematika yang kuat sejak dini. Matematika juga merupakan mata pelajaran yang dapat melatih cara berfikir siswa yaitu berfikir secara logis, kritis dan sistematis. Mengingat begitu pentingnya matematika sebagai seorang guru diharapkan mampu memfasilitasi peserta didik dalam mencapai tujuan pembelajaran matematika. Dengan terciptanya pembelajaran yang berkualitas diharapkan hasil belajar siswa juga akan meningkat.

Hasil belajar merupakan tolak ukur yang digunakan untuk menentukan tingkat keberhasilan siswa dalam mengetahui dan memahami suatu mata pelajaran, biasanya dinyatakan dengan nilai yang berupa huruf atau angka-angka. Hasil belajar dapat berupa keterampilan, nilai dan sikap setelah siswa mengalami proses belajar.

Hasil observasi yang dilakukan di kelas VIII SMPN 16 Padang pada tanggal 22 sampai tanggal 23 Januari 2016, ditemukan bahwa hasil belajar siswa masih rendah dan masih banyak yang belum mencapai Kriteria Ketuntasan Minimal (KKM). Model pembelajaran belum bervariasi sehingga mata pelajaran matematika membosankan bagi siswa.
Untuk mengatasi permasalahan di atas diperlukan model pembelajaran yang tepat sehingga siswa terlibat dalam pembelajaran dan mau berkomunikasi dengan temannya. Untuk itu diterapkan model pembelajaran Berbasis Masalah pada proses pembelajaran matematika. Menurut Tan dalam Rusman (2012:229) menyatakan bahwa "pembelajaran berbasis masalah adalah inovasi dalam pembelajaran karena dalam PBM kemampuan berfikir siswa betul-betul dioptimalkan melalui proses kerja kelompok atau tim yang sistematis, sehingga siswa dapat memberdayakan, mengesah, menguji, $\mathrm{m}$ engembangkan kemampuan berfikirnya secara berkesinambung".

Pelaksanaan model pembelajaran berbasis masalah ini digabungkan dengan teknik berikan uangnya. Teknik ini berupa permainan yang dapat mengembangkan potensi siswa dalam pembelajaran. Ginnis (2008:157-158) menyatakan bahwa "Teknik berikan uangnya adalah sebuah teknik belajar berbentuk permainan yang bersifat menguji pengetahuan dan pemahaman siswa dengan cara yang menyenangkan". Teknik ini mempunyai tujuan agar kemampuan berpikir serta kemandirian siswa dapat meningkat dengan cara yang menyenangkan.

\section{Metode}

Jenis penelitian ini adalah penelitian eksperimen dengan rancangan penelitian random terhadap subjek. Populasi 
penelitian adalah siswa kelas VIII SMPN 216 Padang Tahun Pelajaran 2016/2017 terpilih kelas VIII 6 sebagai kelas eksperimen dan kelas VIII 5 sebagai kelas kontrol. Instrumen yang digunakan adalah tes akhir. Instrumen sebelum digunakan di uji cobakan di kelas VIII SMPN 26 Padang. Hasil uji coba menunjukkan instrumen yang digunakan dapat dipercaya.

\section{Hasil dan Pembahasan}

Hasil analisis tes kelas sampel pada Tabel 1 diperoleh data sebagai berikut:

Tabel 1.

Hasil analisis tes kelas sampel

\begin{tabular}{lcccc}
\hline $\begin{array}{l}\text { Kelas } \\
\text { Sampel }\end{array}$ & $\overline{\boldsymbol{x}}$ & $\boldsymbol{S}$ & $\boldsymbol{x}_{\text {maks }}$ & $\boldsymbol{x}_{\min }$ \\
\hline Eksperimen & 82,34 & 11,21 & 100 & 63 \\
\hline Kontrol & 76,90 & 12,36 & 96 & 50 \\
\hline
\end{tabular}

Berdasarkan Tabel 1 dapat dilihat bahwa nilai rata-rata siswa pada kelas eksperimen lebih tinggi dari nilai rata-rata kelas kontrol dan simpangan baku siswa pada kelas eksperimen lebih rendah daripada simpangan baku kelas kontrol. Hal ini menunjukkan bahwa pada kelas eksperimen memiliki keragaman yang rendah, artinya nilai yang diperoleh siswa tidak tersebar jauh dari nilai rata-rata kelas.

Sebelum dilakukan uji hipotesis, terlebih dahulu dilakukan uji normalitas dan uji homogenitas variansi. Uji normalitas dilakukan menggunakan uji liliefors (Sudjana 2005:466), diperoleh $L_{0}$ kelas eksperimen $=0,0870$ dan $L_{\text {tebel }}=$ 0,1634, sedangkan kelas kontrol diperoleh
$L_{0}=0,1402$ dan $L_{\text {tebel }}=0,1591$. Ini berarti kedua sampel berdistribusi normal karena $L_{\text {hitung }}$ lebih kecil dari $L_{\text {tabel. }}$ Hasil uji homogenitas menggunakan uji $F$ (Walpole 1993:314) menunjukkan bahwa $F_{\left(1-\frac{\alpha}{2}\right)\left(n_{1}-1, n_{2}-1\right)}<F<F_{\left(\frac{\alpha}{2}\right)\left(n_{1}-1, n_{2}-1\right)}$ berarti kedua kelas sampel mempunyai variansi yang homogen.

Setelah dilakukan uji normalitas dan homogenitas terhadap kelas sampel, diketahui bahwa kedua kelas berdistribusi normal dan mempunyai variansi yang homogen, kemudian dilakukan uji $t$ (Sudjana 2005:239), diperoleh $t_{\text {hitung }}=1,78$ dan $t_{\text {tabel }}=1,67$, $t_{\text {hitung }}>t_{\text {tabel }}$ maka tolak $H_{0}$ sehingga hipotesis penelitian diterima. Dengan hasil belajar matematika siswa dengan menerapkan model pembelajaran berbasis masalah disertai teknik berikan uangnya lebih baik daripada rata-rata hasil belajar matematika siswa dengan menerapkan pembelajaran konvensional pada siswa kelas VIII SMP Negeri 16 Padang.

Model pembelajaran berbasis masalah disertai teknik berikan uangnya merupakan pembelajaran dengan cara yang menyenangkan, siswa diberikan permainan yang bersifat menguji, sehingga pada saat permainan berlangsung guru dapat mengetahui sejauh mana pengetahuan dan pemahaman siswa.

Pembelajaran dimulai dengan guru menyampaikan tujuan pembelajaran kemudian guru memberikan suatu permasalahan yang berhubungan pada materi hari itu, guru menjelaskan masalah 
yang akan diberikan, guru membantu siswa mendefenisikan permasalahan, guru mengarahkan siswa bekerja berpasangan serta membagikan kertas flipchart yang digunakan untuk membuat penyelesaian dari permasalahan yang diberikan guru.

Disaat masing-masing pasangan bekerja guru membimbing pasangan mendefenisikan masalah yang diberikan. Guru memberikan waktu sepuluh menit untuk menyelesaikan permasalahan tersebut. Setelah waktu sepuluh menit habis masing-masing pasangan memberikan kertas jawaban mereka kepada pasangan yang duduk dibelakang mereka dan menerima kertas jawaban dari pasangan yang didepan. Setelah itu guru memberikan waktu sepuluh menit lagi untuk melanjutkan jawaban yang diberikan oleh temannya jika jawaban yang dibuat belum selesai atau mengkoreksi jawaban yang kurang tepat. Kemudian jawaban kembali kepada pemiliknya dan masing-masing pasangan membuat kesimpulan di kertas yang diberikan guru. Setelah itu guru meloting nama siswa yang akan mempresentasikan permasalahannya kedepan kelas. Selanjutnya guru memberikan latihan dan guru memberikan penguatan terhadapa materi hari itu.

Pembelajaran di kelas kontrol berlangsung secara konvensional yaitu proses pembelajaran yang biasa dilakukan guru di kelas tersebut. Pertama guru menjelasakan materi pelajaran dan memberikan contoh soal, kemudian siswa diberi latihan.

Tes akhir dilaksanakan di kelas eksperimen dan kelas kontrol. Siswa yang mengikuti tes akhir sebanyak 29 orang pada kelas eksperimen dan 31 orang pada kelas kontrol. Hasil penelitian yang telah dilakukan menunjukan nilai rata- rata siswa kelas eksperimen lebih tinggi dari pada nili rata- rata kelas kontrol. Jawaban tes akhir siswa pada kelas eksperimen dan kelas kontrol dapat dilihat pada Gambar 1.

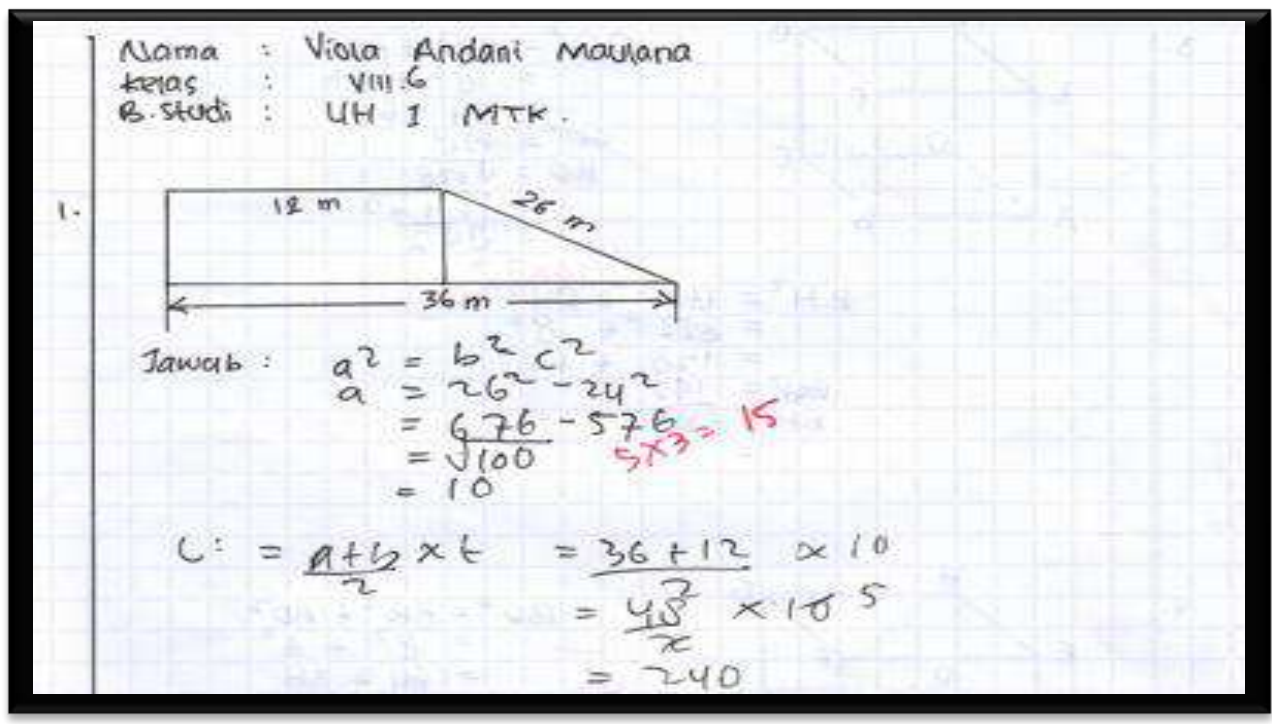

Gambar 1. Contoh lembar jawaban tes akhir kelas eksperimen. 
Berdasarkan Gambar 1, terlihat bahwa siswa pada kelas eksperimen sudah mampu menjawab pertanyaan dengan benar tentang menerapkan Teorema
Pythagoras pada Bidang datar dan ruang. Sedangkan untuk kelas kontrol dapat dilihat pada Gambar 2.

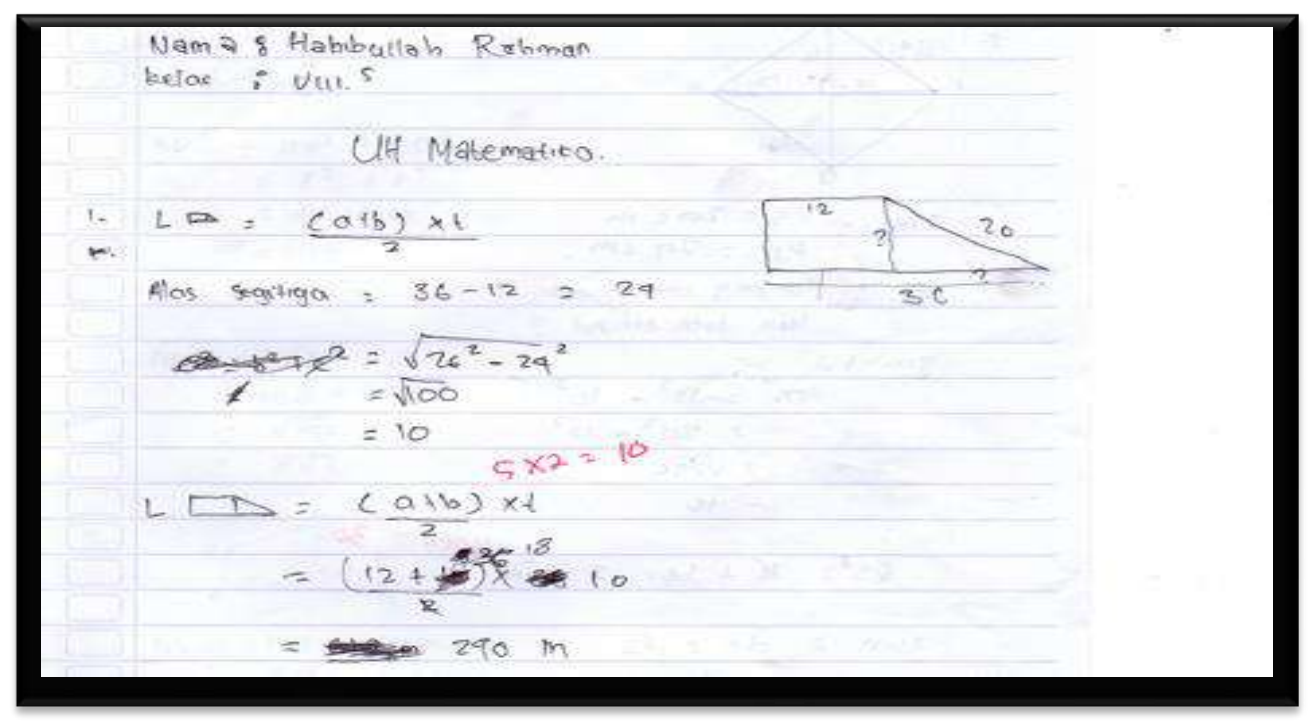

Gambar 2. Contoh lembar jawaban tes akhir kelas kontrol.

Berdasarkan Gambar 2, terlihat bahwa di kelas kontrol siswa sudah memahami soal dengan baik, namun masih ada sedikit kesalahan pada pengoperasian aljabarnya.

\section{Penutup}

Berdasarkan hasil penelitian yang diperoleh, maka dapat disimpulkan bahwa hasil belajar matematika siswa dengan menerapkan model pembelajran berbasis masalah disertai teknik berikan uangnya lebih baik daripada hasil belajar matematika siswa dengan menerapkan pembelajaran Konvensional pada siswa kelas VIII SMP Negeri 16 Padang.

\section{DAftar Pustaka}

Ginnis, Paul. 2008. Trik dan taktik Mengajar. Jakarta: PT Indeks.

Rusman. 2010. Model-Model Pembelajaran. Jakarta: PT Raja Grafindo Persada.

Sudjana. 2005. Penilaian Hasil Proses Belajar Mengajar. Bandung: PT Remaja Rosdakarya . 2005. Metoda Statistika. Bandung: Tarsito.

Walpole, Ronald E. 1993. Pengantar Statistika. Jakarta: Gramedia Pustaka Utama. 
This page is intentionally left blank 